\title{
Africanized honeybees in urban areas: a public health concern
}

\author{
Rodrigo Zaluski ${ }^{[1]}$, Samir Moura Kadri ${ }^{[1]}$, Edison Antonio de Souza ${ }^{[1]}$, \\ Valdinei Moraes Campanucci da Silva ${ }^{[2]}$, Juliane Reis Campanucci da Silva ${ }^{[2]}$, \\ Patricia Rodrigues-Orsi ${ }^{[3]}$ and Ricardo de Oliveira Orsi ${ }^{[3],[4]}$
}

[1]. Programa de Pós Graduação em Zootecnia, Faculdade de Medicina Veterinária e Zootecnia, Universidade Estadual Paulista Júlio de Mesquita Filho, Botucatu, SP. [2]. Secretaria Municipal de Saúde de Botucatu, Prefeitura Municipal de Botucatu, Botucatu, São Paulo, SP. [3]. Centro de Estudos de Venenos e Animais Peçonhentos, Botucatu, SP. [4]. Núcleo de Ensino, Ciência e Tecnologia em Apicultura Racional, Departamento de Produção Animal, Faculdade de Medicina Veterinária e Zootecnia, Universidade Estadual Paulista, Botucatu, SP.

\begin{abstract}
Introduction: This study aimed to investigate the occurrence of Africanized honeybees in Botucatu, São Paulo, Brazil, and to implement a program to remove such swarms. Methods: The occurrences of Africanized honeybee swarms between 2010 and 2012 were studied and strategies to prevent accidents were developed. Results: We noted 1,164 cases of Africanized honeybee occurrences in the city, and 422 swarms were collected. The developed strategies to prevent accidents were disseminated to the population. Conclusions: We contributed to reducing the risks represented by Africanized honeybee swarms in urban areas, by collecting swarms and disseminating strategic information for preventing accidents.
\end{abstract}

Keywords: Accident prevention. Apis mellifera. Urban areas.

European honeybees, of the subspecies Apis mellifera mellifera, were first introduced to Brazil in 1839 from Rio de Janeiro; subsequently, subspecies A. mellifera carnica and A. mellifera ligustica were introduced to the southern regions of Brazil ${ }^{1}$. In 1956, African queen bees (A. mellifera scutellata) were introduced with the aim of increasing hive productivity, because European bees had low productivity and had not adapted well to the Neotropical region. In 1957, 26 swarms of African bees began outcrossing with the European subspecies, giving rise to a fertile hybrid, the Africanized honeybee (AHB) ${ }^{2,3}$. This hybrid adapted well to the floristic and climatic conditions of the Americas, enabling conquest of much of this territory, at a rate of $250-300 \mathrm{~km}$ per year, and reaching the USA in $1990^{4}$.

AHBs are highly productive, but are also highly defensive ${ }^{2}$. They can recruit other bees rapidly to attack and drive away possible invaders from their territory; they respond faster, in greater numbers, and with more stings to any threat to their colony ${ }^{5}$. Compared to European bees, AHBs demonstrate higher foraging activity, reproduction rate, propensity to swarm and abscond, place fewer demands on the site for hosting their colonies, and can travel greater distances to attack intruders or potential predators. Moreover, their attacks can be fatal to humans $2^{2,67}$.

\footnotetext{
Address to: Dr. Ricardo de Oliveira Orsi. NECTAR/Dept ${ }^{\circ}$ Produção Animal/ FMVZ/UNESP. Distrito de Rubião Jr s/n, 18618-000 Botucatu, SP, Brasil.

Phone: 5514 3880-2946

e-mail: orsi@fmvz.unesp.br

Received 4 December 2013

Accepted 3 February 2014
}

Two extremely common behaviors contribute to the spread of AHBs. The first is reproductive behavior or swarming-during periods of food abundance, when the colony's population grows and a new queen emerges. The bees then leave the hive with the original queen to search for a new hive site. The second behavior is absconding-when food sources are scarce and weather conditions are unfavorable for the survival of swarms, when all the bees migrate to another site $^{2}$.

Because swarming and absconding are inherent AHB characteristics, and because of anthropomorphic changes to the environment (agriculture, livestock, reforestation, and construction of cities), the number of swarms that have migrated to and have become established in urban areas has been increasing annually. Urban areas provide numerous sites for the installation of colonies (houses, walls, trees) and resources necessary for their survival (nectar, pollen, water, and resin) $)^{2,6}$.

The AHBs in these areas represents a threat to public health ${ }^{2,48}$. However, AHBs are important for native plant pollination and agricultural production, as well as in producing honey, propolis extract (for use in antibiotics), and royal jelly, which is used in some foods 9 .

AHB-related accidents, involving a single sting or massive attack, are common in rural and urban areas of Brazil' ${ }^{2}$. The severity of these attacks depends on the patient's sensitivity to the apitoxin fraction of bee venom and/or the number of stings received. The pro-inflammatory mediators released during allergic reactions to apitoxin can produce acute inflammatory response, causing disturbances in the immune system, heart, liver, kidney, central nervous system, bone marrow, blood vessels, and skeletal muscle. Hypersensitive individuals may 
develop anaphylaxis, followed by glottal edema and intense urticaria even after a single sting, requiring swift treatment and medication to avoid fatalities ${ }^{8}$. An aggravating factor is the lack of AHB-specific antivenom serum?

We aimed to investigate the occurrence of AHBs in Botucatu, State of São Paulo, Brazil, and to implement a program for removing swarms.

The study was conducted between January 2010 and December 2012, in Botucatu, located in the Midwestern region of the State of São Paulo, southeast Brazil. The region has a Cfa climate according to the Köppen classification and is located at $22^{\circ} 53^{\prime} \mathrm{S}, 48^{\circ} 27^{\prime} \mathrm{W}$, with average annual rainfall of $1,447 \mathrm{~mm}$ and average altitude of $804 \mathrm{~m}$ above sea level.

The study involved a partnership between the Environmental Health Surveillance (EHS) program of the Botucatu Health Department and the Beekeeping Sector (BS) of the College of Veterinary Medicine and Animal Science, University of São Paulo State (UNESP) Botucatu. The occurrence of swarms was reported to the EHS by citizens. Callers' names, addresses, and phone numbers were recorded, along with the date and location of the swarm. Then, a team of collaborators that had been trained by the University isolated the swarm and educated locals on accident prevention. Information about how to prevent accidents was disseminated using electronic (social network, television, governmental website, video) and print (magazines and flyers) media.

Swarm removal was performed at night using methods described by Nogueira-Couto and Couto ${ }^{10}$. The swarms were transported to the BS to be used in research, teaching, and production of bee products.

During the three-year study period, 1,164 occurrences of AHB swarms were reported in Botucatu. Of these, 603 (51.8\%) were colonies (with specific hives containing combs, brood, and food) and $561(48.2 \%)$ were clusters (a cluster of bees that had landed at a given site, but lacking a hive containing honeycomb). A total of 422 (36.2\%) swarms were collected, including $227(53.8 \%)$ colonies and $195(46.2 \%)$ clusters. The remaining 742 (63.8\% of occurrences) swarms were not collected because the bees had abandoned the site, common behavior when the clusters or colonies are located in dangerous places.

The swarms were most often located in abandoned water boxes, wood and pasteboard boxes, bins, or furniture (444; $38.1 \%)$, followed by trees $(251 ; 21.5 \%)$, rooftops of houses $(238 ; 20.5 \%)$, and other constructions [fireplaces, walls, lampposts, sewer inspection boxes, water and energy meter boxes $(231 ; 19.9 \%)$ ], all in urban locations, thereby having a high risk of accidents because of human contact.

Further, we observed a gradual increase in the occurrence of swarms: 182 swarms in 2010, 347 swarms in $2011(190.6 \%$ increase), and 635 swarms in 2012 (348.7\% increase) (Table 1). This may be due to the dissemination of information through the media, encouraging reporting of swarms to reduce the risk of accidents.

February and March of each year had higher numbers of AHB swarms than during other months (Table 1); hence, efforts to relocate swarms and prevent accidents should be intensified during this period.

TABLE 1 - Occurrence of Africanized honeybee swarms and number of swarms collected in Botucatu urban areas, between January 2010 and December 2012.

\begin{tabular}{|c|c|c|c|c|c|c|c|c|}
\hline \multirow[b]{3}{*}{ Month } & \multicolumn{6}{|c|}{ Year } & & \\
\hline & \multicolumn{2}{|c|}{2010} & \multicolumn{2}{|c|}{2011} & \multicolumn{2}{|c|}{2012} & \multicolumn{2}{|c|}{ Total } \\
\hline & occur & collect & occur & collect & occur & $\overline{\text { collect }}$ & occur & collect \\
\hline January & 2 & 0 & 46 & 16 & 30 & 12 & 78 & 28 \\
\hline February & 9 & 3 & 58 & 20 & 136 & 43 & 203 & 66 \\
\hline May & 5 & 2 & 24 & 15 & 79 & 34 & 108 & 51 \\
\hline June & 4 & 2 & 31 & 19 & 61 & 27 & 96 & 48 \\
\hline July & 9 & 2 & 28 & 11 & 41 & 14 & 78 & 27 \\
\hline November & 7 & 3 & 14 & 3 & 32 & 1 & 53 & 7 \\
\hline December & 50 & 18 & 30 & 11 & 28 & 3 & 108 & 32 \\
\hline Total & 182 & 69 & 347 & 147 & 635 & 206 & 1,164 & 422 \\
\hline
\end{tabular}

occur: occurrences; collect: collected. 
Migration of AHB swarms to urban areas is common in Brazil, with increasing number of accidents. Generally, children, elderly people, and allergic individuals suffer greater harm following exposure to poisonous or venomous animals ${ }^{8}$. Data from Information System for Notifiable Diseases, Health Surveillance Secretariat, and Health Ministry show 1,450 reported cases of bee-related accidents in Brazil in 2000; in 2011, this became 9,447 cases, i.e., a $651 \%$ increase. The number of deaths increased from 3 in 2010 to 26 in 2011 $(866 \% \text { increase })^{11}$.

Malaspina et al. ${ }^{12}$ reported that $32 \%$ of patients treated in emergency centers in São Paulo State were victims of accidents involving Hymenoptera (bees, wasps, and ants). A Zoonotic Surveillance Unit of the Health Ministry survey indicated a $157 \%$ increase in bee-related accidents over the past decade. In 2011, over 139,000 bee-related accidents and 293 bee-related deaths were reported in Brazil ${ }^{13}$.

Africanized honeybee attack victims may experience mild symptoms-pain, local inflammation, nausea, tachycardia, and vomiting. In severe cases involving multiple stings, biochemical changes may occur (increased levels of creatine phosphokinase, lactate dehydrogenase, and aspartate/alanine aminotransferase). Autopsy results of an 11-year-old male attacked by an AHB swarm in Botucatu and who had received more than 1,000 stings, showed erythematous-purpuric skin lesions with necrosis at the sting locations, rhabdomyolysis, focal myocardial necrosis, tubular hydropic degeneration and focal acute tubular necrosis of the kidneys, myoglobinuria, and centrilobular necrosis in the liver. The victim died $24 \mathrm{~h}$ after the attack, despite receiving symptomatic treatment ${ }^{7}$.

The effect of AHB poison is intense during the warmer and humid months of the year ${ }^{14}$. These periods promote the growth of insect populations, increasing the demand for food and nesting sites $^{2}$. Almeida et al. ${ }^{7}$ in their study in Botucatu, revealed that most AHB-related accidents occurred in the afternoon and victims involved were aged between 5 and 87 years, receiving between 20 and 500 stings.

No antivenom is available for bee sting ${ }^{7}$. Thus, campaigns for preventing accidents and removing swarms from urban areas are extremely important to safeguard public health. Accident prevention will reduce the demand for health services ${ }^{14}$ and improve people's safety and welfare.

Monitoring AHB swarm occurrences in Botucatu increased our knowledge of this subject, allowed identification of sites and periods of increased incidence of swarms, and allowed the development and dissemination of strategies for preventing accidents. The sites usually chosen by bees are enclosed spaces that favor nesting, such as walls, trees, and houses (Figure 1 and Figure 2). Swarms occurred during periods when resources necessary for their survival are available (nectar, pollen, water, and resin), as bees generally migrate to areas with plentiful resources.

An important strategy for reducing the swarm number in urban areas and preventing accidents is the installation of capture swarm boxes; these boxes are used to entice the bees to nest in the box instead of nesting at other sites. This strategy, proposed

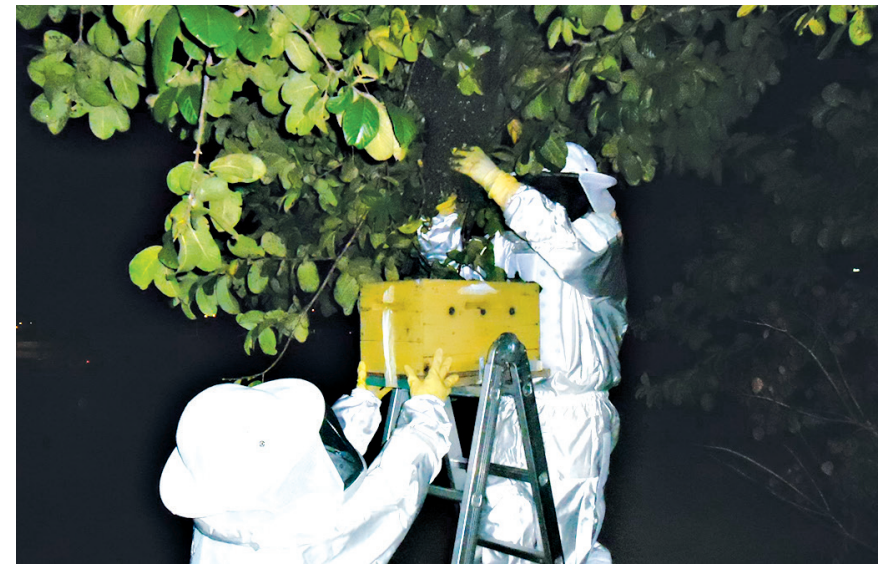

FIGURE 1 - Migratory swarm collection.

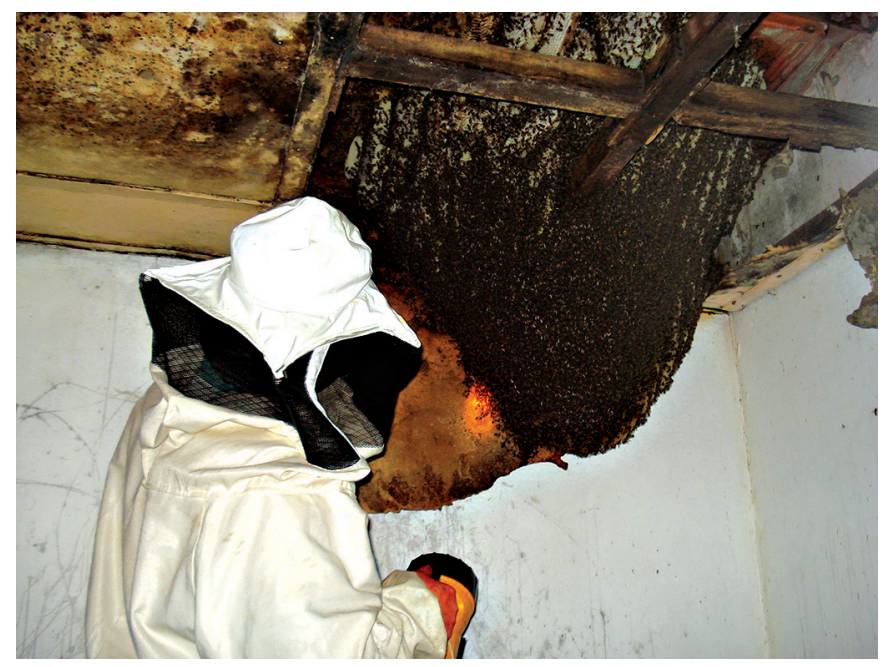

FIGURE 2 - Africanized honeybee swarm under the roof of a building.

by Diniz et al. ${ }^{15}$, proved to be very efficient and practical. After swarms are captured, they can easily be transported to suitable areas where they will not be a threat to the public.

Analysis of swarm occurrences in urban areas suggested that the following actions should be prioritized: remove abandoned materials, which provide refuge for swarms; adequately seal buildings to eliminate cavities and holes that can shelter swarms; observe and report the presence of bees in particular locations; avoid places occupied by AHB swarms; avoid using noisy equipment in places where there are swarms; avoid making sudden movements, throwing objects, or using chemicals attempting to destroy swarms; let experts (trained professionals or experienced beekeepers) collect the swarms; and always wear protective clothing when handling AHB swarms. Children must be taught not to play with or near swarms.

It is extremely important to create awareness among the public about the risks of AHB swarms, steps for preventing 
their establishment in urban areas, and procedures for avoiding accidents. Healthcare professionals can help decrease the threat of AHBs by being well informed, providing information to their patients, and participating in local and regional policy development before AHBs arrive. Similar studies and implementation of programs for monitoring and collecting AHB swarms are recommended for other Brazilian regions and countries where AHB accidents are common and pose risks to the public.

\section{ACKNOWLEDGMENTS}

The authors thank Pró Reitoria de Extensão da Universidade Estadual Paulista Júlio de Mesquita Filho, Botucatu Campus.

\section{CONFLICT OF INTEREST}

The authors declare that there is no conflict of interest.

\section{FINANCIAL SUPPORT}

The present study was partially supported by Pró Reitoria de Extensão da Universidade Estadual Paulista Júlio de Mesquita Filho, Campus Botucatu.

\section{REFERENCES}

1. Crane E. The world history of beekeeping and honey hunting. New York: Routledge; 1999.

2. Pereira AM, Chaud-Netto J. Africanized honeybees: Biological characteristics, urban nesting behavior and accidents caused in Brazilian cities (Hymenoptera: Apidae). Sociobiology 2005; 46:535-550.
3. Pinto MA, Rubink WL, Patton JC, Coulson RN, Johnston JS Africanization in the United States: replacement of feral european honey bees (Apis mellifera L.) by an african hybrid swarm. Genetics 2005; 170:1653-1665

4. Ferreira Jr RS, Sciani JM, Marques-Porto R, Lourenço AJ, Orsi RO, Barraviera B. Pimenta DC. Africanized honeybee (Apis mellifera) venom profiling: Seasonal variation of melittin and phospholipase A2 levels. Toxicon 2010; 56:355-362.

5. Breed MD, Guzmán-Novoa E, Hunt GJ. Defensive behavior of honey bees: Organization, genetics and comparisons with other bees. Annu Rev Entomol 2004; 49:271-298.

6. Baum KA, Tchakerian MD, Thoenes SC, Coulson RN. Africanized honey bees in urban environments: A spatio-temporal analysis. Landscape Urban Plan 2008; 85:123-132.

7. Almeida RAMB, Olivo TET, Mendes RP, Barraviera SRCS, Souza LR, Martins JG, et al. Africanized honeybee stings: how to treat them? Rev Soc Bras Med Trop 2011; 44:755-761.

8. Ferreira Jr RS, Almeida RAMB, Barraviera SRCS, Barraviera B. Historical perspective and human consequences of africanized bee stings in the Americas. J Toxicol Environ Health B 2012; 15:97-108.

9. Orsi RO, Sforcin JM, Funari SRC, Fernandes Jr A, Rodrigues P, Bankova V. Effects of propolis from Brazil and Bulgaria on Salmonella serovars. J Venom Anim Toxins Trop Dis 2007; 13:748-757.

10. Nogueira-Couto RH, Couto LA. Apicultura: manejo e produtos. $3^{\text {rd }}$ ed. Jaboticabal: FUNEP; 2006.

11. Ministério da Saúde. Incidência de acidentes provocados por abelhas no Brasil. [Cited 2013 October 17]. Available at: http://www.portalsaude. saude.gov.br/portalsaude/texto/5848/783/acidentes-por abelhas.html/.

12. Malaspina O, Bueno OC, Augusto AVL, Palma MS. Biologia dos himenópteros sociais. In: Castro FFM, Palma MS, editors. Alergia a venenos de insetos. $1^{\text {st }}$ ed. Barueri: Manole; 2009. p. 5-36.

13. Alves K. Acidentes com animais venenosos crescem 157\% [Internet]. [Cited 2013 September 21]. Available at: http://portalsaude.saude.gov. $\mathrm{br} /$ portalsaude/noticia/8045/162/acidentes-com-animais peconhentoscrescem-157.html.

14. Martins CBG, Andrade SM, Paiva PAB. Envenenamentos acidentais entre menores de 15 anos em município da Região Sul do Brasil. Cad Saude Publica 2006; 22:407-414.

15. Diniz NM, Soares AEE, Pecci VB. Africanized honey bee control program in Ribeirão Preto city, São Paulo, Brazil. Am Bee J 1994; 134:746-748. 